\title{
The Effects of Strategic Is on Firm Performance: An Empirical Study of the Three-Way Interaction Investigation of Turbulent Scenario
}

\author{
Adilson Carlos Yoshikuni (Correspondence author) \\ School of Business Administration of São Paulo da Fundação Getulio Vargas \\ (FGV-EAESP), Phone +55 1137993656 Av. 9 de Julho, 2029, 01313-902, Sao Paulo - SP \\ Brazil.
}

Email: acyoshikuni@hotmail.com \& ayoshikuni@terra.com.br

\begin{abstract}
Alberto Luis Albertin
School of Business Administration of São Paulo da Fundação Getulio Vargas (FGV-EAESP), Phone +55 1137993656 Av. 9 de Julho, 2029, 01313-902, Sao Paulo - SP Brazil.
\end{abstract}

Received: Aug. 20, 2018 Accepted: Sep. 21, 2018 Online published: Oct. 12, 2018 doi:10.5296/jpag.v8i4.13767

URL: https://doi.org/10.5296/jpag.v8i4.13767

\begin{abstract}
The purpose of this article is to explore how the domains of turbulence scenario moderate the relationship between strategic information systems (IS) and firm performance (FP). This research conducts a quantitative survey-based study with partial least squares (PLS) technique employing a sample of 196 firms from different industries located in Brazil that operate under an uncertain environment during an economic crisis. The findings confirm the existence of strong effects in the relationship between strategic IS and firm performance. Essentially, this research further finds that this relationship (strategic IS -> FP) is particularly pronounced in uncertain hostile environments and in cases where GDP is strongly negative by three-way interaction. Thus, the research results helped organizations and managers understand SIS value in the strategy-as-practice approach to Brazilian environmental uncertainty.
\end{abstract}

Keywords: strategic IS, IS strategy, IT business value, firm performance, turbulent scenario 


\section{Introduction}

Information systems (IS) strategy has been studied extensively by researchers and practitioners for decades (Marabelli \& Galliers, 2017; Merali, Papadopoulos, \& Nadkarni, 2012; Teubner, 2013; Ward, 2012). Prior research on strategic IS (Chan \& Huff, 1992) focus on the contribution of IS as a shared organizational perspective on setting and meeting strategic organizational goals (Chen, Mocker, Preston, \& Teubner, 2010; Newkirk \& Lederer, 2006; Philip, 2007). The study, therefore, focuses on strategic IS that refers to the appropriate and timely use of IS to effectively support business strategy to gain or maintain competitive advantage and firm performance (Chen et al., 2010; Johnson \& Lederer, 2013; Leidner, Lo, \& Preston, 2011; Albert H. Segars \& Grover, 1998).

However, most studies on strategic IS theory were conducted on stable economies such as the United States and European countries (Wade \& Hulland, 2004). The contextual factors of a turbulent scenario from economic crisis and an uncertain environment, measured by the level of dynamism, heterogeneity, and hostility, are rarely considered in the relationship between strategic IS and firm performance in developing countries (Merali et al., 2012; Teubner, 2013). According to Melville et al., (2004), the domains of competitive macro environment influences the creation of IS business value to achieve corporate performance.

Hence, this study has two main objectives. The first objective is to test the relation between strategic IS and firm performance in a developing country setting. The second is to investigate the moderation (two- and three-way interaction effects) of environmental uncertainty and a turbulent economy (GDP) in the relation.

The paper is divided in theory and hypothesis development for this study, the methodology of data collection and analysis are presents the findings of the study, discussions and conclusions, and finally the study examines the implications for practice, and identifies limitations of the study, and outlines future research directions.

\section{Theory and Hypothesis Development}

\subsection{Firm Performance}

Models of organizational performance have tended to gauge success along one of two lines financial or non-financial outcomes (Sunil Mithas, Ramasubbu, \& Sambamurthy, 2011; Mostaghel, Oghazi, Beheshi, \& Hultman, 2015). According to Chan, Sabherwal and Thatcher (2006) firm performance could be measured by perceived operational and financial performance. Financial measurements represent the long-term value of firm performance (Atkinson, Kaplan, Matsumura, \& Young, 2011; Kim, Shin, Kim, \& Lee, 2011; Park, Lee, \& Chae, 2017a) and are the result of organizational effectiveness in strategy implementation, productivity, and revenue growth (Kaplan \& Norton, 2008; Ouakouak \& Ouedraogo, 2013).

According to Kaplan and Norton (2008), to achieve long-term value for shareholders, it is necessary to understand customer performance and environmental conditions (Ong \& Teh, 2009; Yoshikuni \& Albertin, 2017; Yoshikuni, Machado-da-silva, Albertin, \& Meirelles, 2014). Customer performance is measured by client satisfaction with the quality of products 
and services, customer relationships, customer retention, and brand image (Kaplan \& Norton, 2008; Park, Lee, \& Chae, 2017b). Therefore, the delivery of attributes demanded by customers can promote customer satisfaction (Mostaghel et al., 2015) and retention (S. Mithas, Tafti, \& Mitchell, 2013; Yoshikuni \& Albertin, 2014).

\subsection{Strategic Information Systems}

The literature on strategy management provides many conceptualizations to explain the relationship between business strategy and organization performance, and strategy researchers have discussed the strategy construct from various angles (Mintzberg, Ahlstrand, \& Lampel, 2009). However, a stream of strategy management that received considerable attention was strategic planning (SP), which represents comprehensive systems composed of interrelated activities such as strategic objectives, environmental analysis, strategy formulation, strategy implementation, and strategic control to achieve or maintain competitive advantage and improve firm performance (Grant, 2003; Hill, Jones, \& Schilling, 2014; Kaplan \& Norton, 2008; Kenworthy \& Verbeke, 2015; Wolf \& Floyd, 2017).

The focus of this study is on strategic IS that supports business strategy processes. Strategic IS is defined as the process of identifying a portfolio of information system applications that will support an organization's business plans (Sabherwal \& Chan, 2001) to enable firm strategic planning capability to achieve business goals (Newkirk \& Lederer, 2006; Philip, 2007; A.H. Segars, Grover, \& Teng, 1998; Singh, Watson, \& Watson, 2002). Strategic IS enables business strategy success and implies that the firm has the capability to effectively focus on cooperative work as part of IS/IT applications (Chen et al., 2010; Marabelli \& Galliers, 2017; Merali et al., 2012; Whittington, 2014). In addition, Strategic IS synchronized group communication and collaboration develops dynamic and improvisational capabilities to achieve competitive advantage. According to authors (Pavlou \& El Sawy, 2006, 2010; Yoshikuni \& Albertin, 2017), strategic IS enables dynamic capabilities by reconfiguring existing operational capabilities to better match the environment changes.

Conceptually, strategic IS should not be examined as part of a strategy (Chen et al., 2010; Whittington, 2014); strategy and IS should be embedded in each other. According to Kohli and Grover (2008), IS-embedded business as a capability required by an organization can and does exist without information systems. Strategic IS from the strategy-as-practice perspective resonates and reinforces the idea that IS and business strategy matter only when they become embedded in strategic planning routines (Arvidsson, Holmström, \& Lyytinen, 2014; Marabelli \& Galliers, 2017; Whittington, 2014).

As mentioned earlier, the fundamental objective of strategic planning is to impact firm performance (Hill et al., 2014; Kaplan \& Norton, 2008; Kenworthy \& Verbeke, 2015), and the effective use of strategic IS enables capabilities and creates many benefits for strategic planning phases. Thus, strategic IS supports and communicates strategic objectives (Philip, 2007; Sabherwal \& King, 1995; Singh et al., 2002; Yoshikuni \& Albertin, 2014), enables environmental analysis to scan external factors and identify key internal resources (Dameron, Lê, \& Lebaron, 2015; Davenport, Harris, \& Morison, 2010; Kaplan \& Norton, 2008; Rouhani, Ashrafi, Ravasan, \& Afshari, 2016; Yoshikuni \& Albertin, 2017), formulates strategies into 
action plans (Arvidsson et al., 2014; Kearns \& Sabherwal, 2006; Leidner et al., 2011; Merali et al., 2012), coordinates work projects and support actions to implement strategy (Dameron et al., 2015; Maharaj \& Brown, 2015; Newkirk \& Lederer, 2006; Singh et al., 2002), helps strategic controls to compare performance against budgets and goals (Davenport et al., 2010; Kaplan \& Norton, 2008; Rouhani et al., 2016; Sabherwal \& Chan, 2001; Shollo \& Galliers, 2016), and boosts competitive advantage. According to Yoshikuni, Favaretto, Albertin and Meirelles (2018) SIS incorporates the strategic planning process and facilitates the cooperation, analysis and participation of employees, enabling them to think about, analyze, deploy and follow strategic planning through the IT/IS portfolios.

Several studies show that strategic IS improves firm performance in a stable economy such as the United States and European countries (Chan \& Huff, 1992; Kim et al., 2011; Merali et al., 2012; Sabherwal \& Chan, 2001; Teubner, 2013). Hence, this study posits that strategic IS enables capabilities and creates several benefits for all strategic planning phases (Chen et al., 2010; Johnson \& Lederer, 2013; Leidner et al., 2011; Yoshikuni et al., 2018) to enhance firm performance in developing countries (Yayla \& Hu, 2012). Thus, the following hypothesis is predicted for strategic IS related to firm performance:

\section{H1: Strategic IS positively affects firm performance.}

\subsection{Environmental Uncertainty}

Environmental uncertainty is a key variable in strategy theory (Hill et al., 2014). It has historically been characterized and studied along three dimensions: dynamism (DY), heterogeneity (HE), and hostility (HO) (Mikalefdletear \& Pateli, 2017; Miller \& Friesen, 1983; Newkirk \& Lederer, 2006).

The heterogeneity dimension is related to the complexity and diversity of external environmental factors that affect marketing and production processes (Miller \& Friesen, 1983). Conceptions of market turbulence are based on a firm's evaluation of changes in customer preferences, the ease of forecasting other changes in the marketplace, and the shifting nature of customer bases (Wilden \& Gudergan, 2015). Researchers have operationalized heterogeneity by quantifying changes in customers' buying habits, the diversity of competitors in a given market, and variability in product lines (Newkirk \& Lederer, 2006). The heterogeneity component of environmental uncertainty suggests that when market diversity increases (in terms of either competitors or customers), firms require more information to understand the environment to create competitive strategies. Moreover, bounded rationality limits managers' capacities to effectively assess the environment when it is characterized by heterogeneity (Mao, Liu, \& Zhang, 2014; Ray, Wu, \& Konana, 2009; Yayla \& $\mathrm{Hu}, 2012)$.

The dynamism dimension of environmental uncertainty relates to the rate at which a given environment changes (i.e., market volatility) (Mikalef \& Pateli, 2017; Newkirk \& Lederer, 2006; Schilke, 2014; Yoshikuni et al., 2018). High rates of environmental change make it difficult for managers to predict future events and their impact on the organization (Lumpkin \& Dess, 2001). High levels of dynamism also make it difficult for managers to adopt 
strategies quickly enough to effectively deal with a fast-changing environment (Yayla \& $\mathrm{Hu}$, 2012). The dynamic environment puts pressure on managers who require frequent environment information to identify opportunities and understand the effects of the market and customer changes in the business environment (Chanchun, Sabherwal, \& Thatcher, 2006; Pavlou \& El Sawy, 2006).

Finally, the hostility dimension relates to the threats firms face because of environmental turbulence (Yayla \& Hu, 2012). The hostility dimension is also used to indicate the scarcity of resources and the intensity with which actors in a given market compete for those resources (Lumpkin \& Dess, 2001; Mao et al., 2014). The competitive turbulence index assesses the general degree of the competition in a market, the extent to which competitive firms engage in promotion and price wars, the ability of firms to match competitive offers, and the rate at which firms make competitive moves (Chanchun et al., 2006; Wilden \& Gudergan, 2015). Given the various ways that the hostility dimension has been conceptualized, it relates to the degree of competition in the external environment and the availability of resources for competing firms (Newkirk \& Lederer, 2006; Wilden \& Gudergan, 2015). Hence, firms need frequent information to understand market characteristics and customer trends; to regularly appraise competitors and their products; and to develop competitive strategies (Hitt, Keats, \& DeMarie, 1998; Pavlou \& El Sawy, 2010).

Some studies of IS literature have shown that external factors, such as competition and business environment, influence many aspects of IS strategy (Chanchun et al., 2006; Lederer \& Mendelow, 1986; Mikalefdletear \& Pateli, 2017; Vijayasarathy \& Sabherwal, 1994). Melville et al. (2004) argue that a competitive environment promotes different impacts of IT/IS business value and business performance, and Newkirk and Lederer (2006) corroborate that there are various influences on strategic planning capabilities depending on the sources of dynamism, hostility, and heterogeneity in the uncertain environment. Thus, the degree of instability generated by the unpredictability of environmental uncertainty demands information for decision making implying that IS are an important determinant of the strategic planning process (Ray et al., 2009; Yayla \& Hu, 2012). Additionally, analysis in uncertain environments might be expected to produce greater knowledge on competitors, resources, customers, and regulators (Pavlou \& El Sawy, 2010). This would make it possible to understand and predict change and, thus, enable the development of strategic plans (Newkirk \& Lederer, 2006). Strategic IS enables cooperative work that spontaneously creates knowledge to address novel situations by brainstorming. Diverse ideas are rapidly integrated enabling collective reactions to a turbulent environment (Pavlou \& El Sawy, 2010). Therefore, there is a consensus in turbulent environments that IS strategy is more valuable (Hitt et al., 1998; Mikalefdletear \& Pateli, 2017; Pavlou \& El Sawy, 2006; Yayla \& Hu, 2012) in providing real-time information to enable firm improvisational and dynamic capabilities (Pavlou \& El Sawy, 2010). Hence, strategic IS coordinates strategic planning capabilities and allows decision support to be flexible and agile in responding to the impact of the uncertain competitive environment (Yoshikuni et al., 2018). This leads to the next hypothesis:

H2: The effect of strategic IS on firm performance is moderated by the dimensions of environmental uncertainty. 


\subsection{Control Variables}

Control variables (CV) are critical in management research because they simplify the interpretation of findings that result from statistical analyses (Carlson \& Wu, 2012). Organizational size (i.e., number of employees [SIZE], (Chanchun et al., 2006) and sector GDP are used as external factors of the macro environment and industry characteristics as CVs (Melville, Kraemer, \& Gurbaxani, 2004) to identify the influence on the relationship between strategic IS and firm performance. Mintzberg, Ahlstrand, and Lampel (2009) and Hill et al. (2014) find that GDP is a major economic external factor in the macro environment that influences strategic planning and business performance. GDP is one of the primary indicators used to gauge the health of a country's economy. It represents the total monetary value of all goods and services produced over a specific period (I.M.F., 2016). Negative GDP demonstrates that organizations decreased in size, revenues, and performance (I.M.F., 2016). In an uncertain environment, customers can reduce their purchases, inventories can rapidly increase, and vendors can demand prompter payments causing revenues to plunge, costs to escalate, and profits to vanish (Chanchun et al., 2006; Newkirk \& Lederer, 2006). A turbulent environment describes the general conditions of unpredictability, and the effective use of IS leverages strategy projects, key resources, and cooperative work to develop dynamic and improvisational capabilities to achieve better performance (Pavlou \& El Sawy, 2010). Thus, based on the value that strategic IS creates for the strategic planning process to improve business performance (Chen et al., 2010; Johnson \& Lederer, 2013; Leidner et al., 2011; Marabelli \& Galliers, 2017; Albert H. Segars \& Grover, 1998), strategic IS should enable strategic planning capabilities allowing organizations to gain competitive advantage and improve firm performance in a turbulent economy (I.M.F., 2016; IBGE, 2016) and uncertain environment. This, leads to the next hypotheses:

H3: The effect of strategic IS on firm performance is moderated by control variables.

H4: The effect of strategic IS on firm performance is moderated by three-way interaction between environmental uncertainty and control variables.

H4 was developed to test the three-way interaction between environmental uncertainty and control variables and its moderating effect on the relationship between strategic IS and FP. Hence, GDP per sector and SIZE moderate environmental uncertainty, and these effects moderate the relationship between strategic IS and FP.

Figure 1 below illustrates the hypotheses resulting in the conceptual model. 


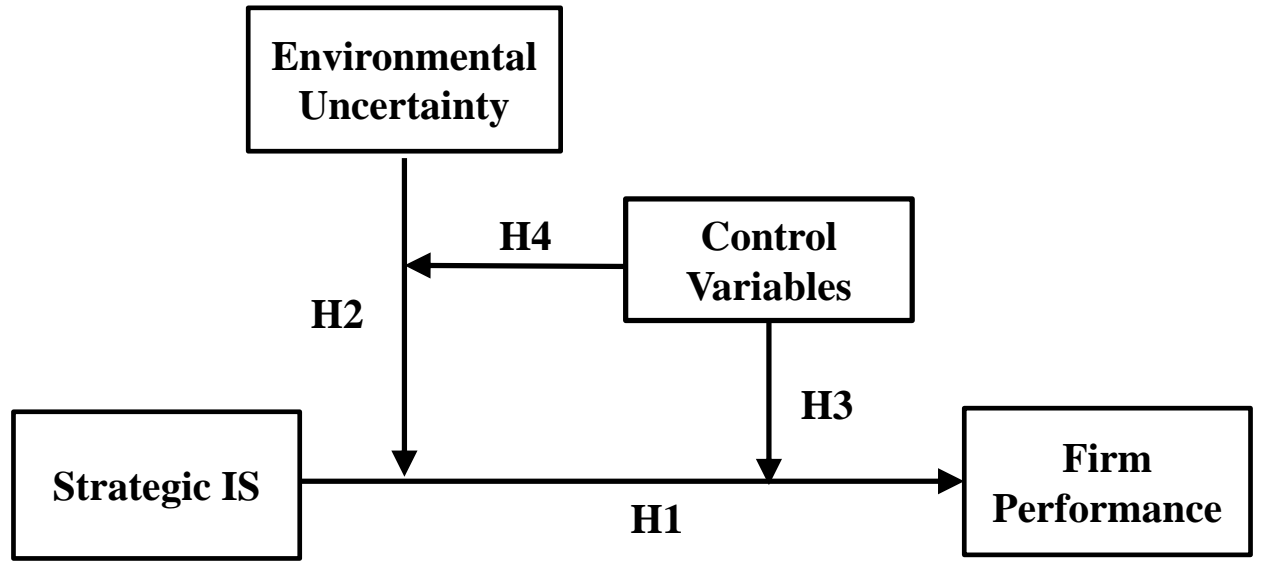

Additionally, Chin et al.'s (2013) measured marker variable technique (MLMV) is used to evaluate the controls for common method bias. Finally, for the sake of visual simplicity, the indicators for the constructs are omitted from the model visualizations.

\section{Methodology}

This section describes the sample, the data they provided, the approach to analyze the data, and the statistical analysis techniques employed.

\subsection{Sample}

To test the hypotheses, Brazilian company data were chosen because of the current instability in the Brazilian economy and political institutions (external factor of macro environment). According to IBGE $(2016,2017,2018)$, Brazilian GDP decreased by 3.8 per cent in 2015, in 2016 GDP shrank 3.4 per cent and Brazilian GDP grows 1.0\% in 2017, after 2 years of retraction. Similarly, the Brazilian account deficit fell from \$104 billion USD in 2014 to \$59 billion USD in 2015 (I.M.F., 2016). According to IMF (2017) Brazilian growth is projected to be 1.3 percent in 2018, moving towards 2 percent in the medium term and Inflation is projected to undershoot its central target of 4.5 percent in 2018. As a further illustration of Brazil's economic difficulties, the IBGE (2016) reported that changes in the GDPs of various sectors (GDP per sector) were suboptimal in 2015. The manufacturing (-6.2 per cent), services ( -2.7 per cent), and government (-1.0 per cent) sectors all experienced declines in GDP in 2015 (relative to 2014). The only sector to grow in terms of GDP was agribusiness (+1.8 per cent), and its rate of growth was modest at best. IBGE (2016). Given the difficulties faced by the Brazilian economy (as indicated by GDP and deficit trends), this economy represents an ideal setting for testing the moderating effect of an uncertain economic environment.

A questionnaire was designed to evaluate participants' perceptions related to strategic IS, which is one method of determining the business value of IT/IS (Tallon, Kraemer, \& Gurbaxani, 2000) under environmental uncertainty, firm performance, and the aforementioned control variables. The perception executive method has been subsequently used in several other IT/IS studies (Kim et al., 2011; Papke-Shields, Malhotra, \& Grover, 2006). Statistical techniques were applied to detect and, where possible, to control for common 
method bias. Specifically, four items were designed to have the lowest possible logical correlation with the other constructs under investigation. The MLMV technique was performed on the model at the firm-performance level according to Chin et al. (2013).

The study referenced extant literature in the areas of IS, uncertain environment, and firm performance to develop the items that composed the questionnaire. Past research by Hair et al. (2009) and Sekaran (2000) provided guidance concerning the variables' content validity, the number of categories for the items, and other issues related to survey design. All items were assessed according to a seven-point Likert-type scale ranging from 1 (strongly disagree) to 7 (strongly agree). Table I. Summarizes the measures employed and the sources of the variables.

Table I. Measures and variable sources

\begin{tabular}{|c|c|c|}
\hline Variables & Measures & Sources \\
\hline Strategic IS & $\begin{array}{c}\text { Strategic objectives } \\
\text { Environmental } \\
\text { analysis } \\
\text { Strategy formulation } \\
\text { Strategy } \\
\text { implementation } \\
\text { Strategic control }\end{array}$ & $\begin{array}{l}\text { Singh et al. (2002); } \\
\text { Newkirk and Lederer } \\
\text { (2006); Yoshikuni et } \\
\text { al. }(2018)\end{array}$ \\
\hline Firm performance & $\begin{array}{c}\text { Market performance } \\
\text { Financial } \\
\text { performance }\end{array}$ & $\begin{array}{c}\text { Cho and Pucik } \\
\text { (2005); Kaplan and } \\
\text { Norton (2008); } \\
\text { Atkinson } \text { et al. } \\
\text { (2011); Ouakouak } \\
\text { and Ouedraogo } \\
\text { (2013). }\end{array}$ \\
\hline $\begin{array}{l}\text { Environmental } \\
\text { uncertainty }\end{array}$ & $\begin{array}{l}\text { Dynamism } \\
\text { Heterogeneity } \\
\text { Hostility }\end{array}$ & $\begin{array}{l}\text { Newkirk and Lederer } \\
\text { (2006); Yayla and } \\
\text { Hu (2012); Mikalef } \\
\text { et al. (2017) }\end{array}$ \\
\hline Control variables & $\begin{array}{c}\text { GDP } \\
\text { Organizational size }\end{array}$ & $\begin{array}{l}\text { Cano et al. (2004); } \\
\text { Ray et al. (2009); } \\
\text { IBGE (2016). }\end{array}$ \\
\hline
\end{tabular}

\subsection{Data}

A sample was selected from Brazilian companies in the directories provided by the Center for Applied Information Technology [GVCia] at Fundação Getulio Vargas (FGV). Key informant methodology in which respondents were chosen based on their position, experience, and professional knowledge (Kim et al., 2011) was the method used to obtain the sample. The respondents provide reliable information on group-wise or firm characteristics that is less biased by personal attitudes or behaviors, consistent with the recommendation of Tallon, Kramer, and Gurbaxani (2000). The target respondents included senior business administrators with adequate knowledge of IS and business strategizing processes.

The survey was administered via email by distributing questionnaires to 617 organizations (see Appendix A), 228 (37 per cent) of which were returned. Thirty-two of the returned 
questionnaires had missing data; these response sets were removed from the analyses yielding a final sample size of 196.

This sample size satisfied requirements for partial least squares path modeling (PLS-PM) (Henseler, Ringle, \& Sinkovics, 2009; Sosik, Kahai, \& Piovoso, 2009; Urbach \& Ahlemann, 2010). The literature on PLS-PM mandates that a sample be no less than 10 times the number of structural paths that predict a given reflective construct (Hair, Hult, Ringle, \& Sarstedt, 2013). Although the sample size satisfied this requirement, a more rigorous test of the study's minimum sample size was performed using $G^{*}$ Power Version 3.1.9.2 to calculate the statistical power of the sample size (Faul, Erdfelder, Lang, \& Buchner, 2007). Cohen (1988) and Hair et al. (2013) recommended that when identifying moderate effects (i.e., median effect size $\left[f^{2}\right]$ of 0.15 ), statistical power should be no lower than 0.80 . Using these parameters, $G^{*}$ Power recommended a minimum sample size of 124 cases. The sample of 196 cases was sufficiently large to produce consistent results in the model testing.

Of those that returned questionnaires on behalf of their respective organizations, 39 per cent were C-level personnel, 31 per cent were management and coordination personnel, and 30 per cent were supervisors with decision-making power.

Table II describes the composition of the sample firms in terms of the sector in which they operate and the number of workers they employ.

Table II. Demographic profile of the sample $(\mathrm{N}=196$ organizations $)$

\begin{tabular}{cccc}
\hline Sector & & No. employees & \\
\hline Agribusiness & $5 \%$ & $\leq 9$ & $5 \%$ \\
Government & $1 \%$ & $10-49$ & $9 \%$ \\
Manufacturing & $30 \%$ & $50-99$ & $11 \%$ \\
Service & $64 \%$ & $100-249$ & $10 \%$ \\
Government & $2 \%$ & $250-499$ & $9 \%$ \\
& & $\geq 500$ & $56 \%$ \\
\hline
\end{tabular}

As evidenced by the data in Table II, the sample was heavily populated by firms in the services and manufacturing sectors (94 per cent of companies surveyed). Similarly, organizations with over 500 employees (56 per cent) were more heavily represented in the sample than firms of other sizes.

\subsection{Analysis}

The partial least squares - path modeling (PLS-PM) method is considered the most appropriate in exploratory contexts since it has no assumptions about the distribution of data (normality) and is less demanding in terms of sample size of the sample, which is based on the reproduction of the covariance matrix (AMOS, LISREL, EQS, etc.) (Hair et al., 2013). In addition, PLS-PM was used to perform all relevant statistical analyses on the variables (and relationships between them) (Hair et al., 2013). PLS-PM was used as the analytical method because several past IT researchers have used it to address common issues that involve the simultaneous analysis of multiple variables (e.g., asymmetric variable distributions, limited data (Ringle, Sarstedt, \& Straub, 2012). Previous work in this domain has shown PLS-PM to be robust and particularly applicable to research questions concerning IT/IS and firm 
performance (Ringle, Bido, \& Da Silva, 2014). SmartPLS 2.0 M3 was used to perform all PLS-PM analyses (Ringle, Wende, \& Will, 2005).

To evaluate the normality of all variables prior to analysis, each measure's distribution for asymmetry (as indicated by the coefficient Sk) and kurtosis $(\mathrm{Ku})$ was checked. No variable was sufficiently abnormal to warrant correction (all $|\mathrm{Sk}|<3$ and $|\mathrm{Ku}|<10$; Marôco, 2010). See Table III for a summary of these statistics.

\section{Results}

In this section, the results of the analyses as they pertain to the measurement and structural models as well as the reflective constructs are described along with the results of the hypothesis tests.

\subsection{Measurement Model}

The reflective components of the measurement model were first evaluated by checking their internal consistency, indicator reliability, convergent validity, and discriminant validity (Hair et al., 2013).

To obtain the convergent validity and Average Variance Extracted (AVE; values greater than 0.50 are preferred) of the reflective constructs, Fornell and Larcker (1981) criteria (Henseler et al., 2009; Ringle et al., 2014) were used. Composite reliability (CR) is the most reasonable measure of reliability for PLS-PM because it prioritizes the variables according to their respective reliabilities (Ringle et al., 2014). CR values greater than 0.70 are considered internally consistent (Rouhani et al., 2016) although values greater than 0.90 are too strongly unidimensional (Hair et al., 2013). To analyze the validity of the model's constructs, the Fornell-Larcker criterion was compared to the square root of the constructs' AVE values with highest latent variable correlation with any other construct (Henseler et al., 2009); see Table III). A bootstrapping method determined the statistical significance of the tests $(\mathrm{N}=196$; 1,000 replications).

The outer loadings were analyzed, and the cross loading was observed to evaluate the model's discriminant validity, (Hair et al., 2013). The indicators with lower (value < 0.40) factorial loads in their respective LV (or constructs) than others were deleted (HE_1 and HE_2). See Appendix B.

Convergent validity and the square root of the strategy indicator's AVE were also evaluated. Table III shows that all AVE and internal consistency values (should be greater than 0.70) were acceptable. Moreover, indicators with outer loadings between 0.50 and 0.70 because of increases in AVE and composite reliability above the threshold values suggested by Hair et al. (2013) were considered. Table IV shows that the indicators have higher factor loadings on their assigned constructs and lower factor loadings on other constructs, thereby indicating discriminant validity (Ringle et al., 2014; Urbach \& Ahlemann, 2010). 
Table III. Pearson correlations and descriptive statistics for latent variables

\begin{tabular}{lccccccccc}
\hline Latent variables & 1 & 2 & 3 & 4 & 5 & 6 & 7 & 8 & 9 \\
\hline 1 - Strategic objectives & $\mathbf{0 . 8 2}$ & & & & & & & & \\
2 - Environmental scanning & 0.61 & $\mathbf{0 . 8 2}$ & & & & & & & \\
3 - Strategy formulation & 0.62 & 0.71 & $\mathbf{0 . 8 4}$ & & & & & & \\
4 - Strategy implementation & 0.69 & 0.56 & 0.60 & $\mathbf{0 . 8 1}$ & & & & & \\
5 - Strategy control & 0.58 & 0.60 & 0.59 & 0.56 & $\mathbf{0 . 7 6}$ & & & & \\
6 - Firm performance & 0.53 & 0.53 & 0.52 & 0.51 & 0.44 & $\mathbf{0 . 7 8}$ & & & \\
7 - Dynamism & 0.16 & 0.18 & 0.18 & 0.23 & 0.18 & 0.19 & $\mathbf{0 . 7 7}$ & & \\
8 - Heterogeneity & 0.30 & 0.35 & 0.31 & 0.31 & 0.31 & 0.24 & 0.37 & $\mathbf{0 . 7 5}$ & \\
9 - Hostility & -0.09 & -0.04 & -0.07 & -0.04 & -0.15 & -0.17 & 0.23 & 0.10 & $\mathbf{0 . 7 2}$ \\
\hline AVE & 0.68 & 0.67 & 0.71 & 0.66 & 0.58 & 0.61 & 0.59 & 0.56 & 0.52 \\
Composite reliability & 0.86 & 0.86 & 0.88 & 0.85 & 0.81 & 0.88 & 0.81 & 0.79 & 0.76 \\
Mean & 4.82 & 4.94 & 4.70 & 4.55 & 5.10 & 4.94 & 3.69 & 4.66 & 3.92 \\
Standard deviation & 1.28 & 1.36 & 1.27 & 1.23 & 1.23 & 1.20 & 1.36 & 1.38 & 1.42 \\
Variance coefficient & 0.26 & 0.27 & 0.27 & 0.27 & 0.24 & 0.24 & 0.37 & 0.30 & 0.36 \\
Skewness |Sk| & 0.23 & 0.41 & 0.25 & 0.10 & 0.61 & 0.50 & 0.20 & 0.25 & 0.13 \\
Kurtosis |Ku| & 0.70 & 0.66 & 0.69 & 0.38 & 0.08 & 0.39 & 0.63 & 0.74 & 0.56 \\
\hline
\end{tabular}

The second-order SM variable yielded an AVE value of 0.659 and a CR estimate of 0.91. A comparison of the Fornell-Larcker criterion to the square root of SM (0.812) AVE values showed the criterion to be satisfied.

\subsection{Structural Model}

Variance inflation factor (VIF) values were evaluated to test for multicollinearity among the model's constructs, the highest of which was for strategy formulation (2.418). All VIF values were well below the recommended limit of five (Marôco, 2010). Given that the VIF values for all constructs were low, no evidence was found to suggest the presence of multicollinearity in the data.

Chin et al.'s (2013) MLMV technique was applied to control for common method bias. Specifically, four items were designed to have the least possible logical correlation with other constructs under investigation (see Table IV). These items were intended to capture existing common method variance, if any.

Table IV. Formative indicators used for the MLMV analysis

MLMV_1: It's easy for me to reach my goals.

MLMV_2: I never abandon the desire to have my own business.

MLMV_3: I have a positive attitude towards others.

MLMV_4: I always imagine my house in the future.

The results of the MLMV analysis showed that all differences of $\beta 1$ and $\beta 2$ were insignificant (maximum value of the difference was 0.03$)$, and Case 2 was non-significant $(0.103 ; p>0.05)$ indicating that common method bias was unlikely to be of significant concern for this study, 
see Table V.

Table V. Relationships between latent variables and MLMV

\begin{tabular}{clccccc}
\hline Case & Relationships & $\beta$ & S.E. & $\mathrm{t}$ & p-value & $\mathrm{R}^{2}$ \\
\hline \multirow{4}{*}{1} & Strategic IS $\rightarrow$ FP & 0.578 & 0.0226 & 37.592 & 0.000 & \\
& DY $\rightarrow$ FP & 0.093 & 0.0582 & 1.598 & 0.110 & $\mathbf{3 9 . 5 0 \%}$ \\
& HE $\rightarrow$ FP & -0.001 & 0.0749 & 0.012 & 0.990 & \\
& HO $\rightarrow$ FP & -0.140 & 0.0784 & 1.781 & 0.074 & \\
\hline \multirow{4}{*}{2} & Strategic IS $\rightarrow$ FP & 0.520 & 0.0651 & 7.9877 & 0.000 & \\
& DY $\rightarrow$ FP & 0.088 & 0.0546 & 1.6131 & 0.107 & \\
& HE $\rightarrow$ FP & 0.030 & 0.0743 & 0.4069 & 0.684 & $\mathbf{4 0 . 6 0 \%}$ \\
& HO $\rightarrow$ FP & -0.134 & 0.0659 & 2.0359 & 0.042 & \\
& MLMV - FP & 0.117 & 0.0718 & 1.6312 & 0.103 & \\
\hline
\end{tabular}

\subsection{Continuous Moderator Effect}

A cascaded moderator analysis with three-way interaction (Henseler \& Fassott, 2010) was used to analyze the continuous moderator effects of environmental uncertainty (as indexed by DY, HE, and HO) and the aforementioned control variables (i.e., GDP per sector [GDPS] and organizational size [SIZE]) on the relationship between beginning strategic IS and FP. Tables VI, VII, and VIII illustrate how these various moderators affect the strategic IS-FP relation.

Table VI. Interaction effects of dynamism and control variables on the relationship between strategic IS and FP

In both Cases 1 and 2, the two- and three-way interactions were not significant ( $p>0.05)$.

\begin{tabular}{clccccc}
\hline $\begin{array}{c}\text { Ca } \\
\text { se }\end{array}$ & \multicolumn{1}{c}{ Relationship } & $\beta$ & S.E. & t & p-value & $\mathrm{R}^{2}$ \\
\hline \multirow{4}{*}{1} & DY $\rightarrow$ FP & 0.046 & 0.058 & 0.788 & 0.430 & \\
& DY $\times$ GDPS $\rightarrow$ FP & -0.055 & 0.064 & 0.862 & 0.389 & \\
& GDP $\rightarrow$ PF & -0.004 & 0.063 & 0.068 & 0.945 & $\mathbf{4 1 . 5 0 \%}$ \\
& Strategic IS $\rightarrow$ FP & 0.562 & 0.056 & 9.986 & 0.000 & \\
& Strategic IS $\times$ DY $\rightarrow$ FP & 0.158 & 0.177 & 0.893 & 0.372 & \\
& Strategic IS $\times$ DY $\times$ GDPS $\rightarrow$ FP & 0.076 & 0.090 & 0.841 & 0.401 & \\
& Strategic IS $\times$ GDPS $\rightarrow$ FP & 0.056 & 0.113 & 0.495 & 0.620 & \\
& DY $\rightarrow$ FP & 0.022 & 0.061 & 0.371 & 0.710 & \\
& DY $\times$ SIZE $\rightarrow$ FP & 0.031 & 0.057 & 0.537 & 0.591 & \\
& SIZE $\rightarrow$ FP & 0.112 & 0.058 & 1.949 & 0.050 & \\
Strategic IS $\rightarrow$ FP & 0.530 & 0.06 & 8.281 & 0.000 & $\mathbf{4 3 . 3 1 \%}$ \\
& Strategic IS $\times$ DY $\rightarrow$ FP & 0.140 & 0.166 & 0.842 & 0.400 & \\
& Strategic IS $\times$ DY $\times$ SIZE $\rightarrow$ FP & 0.110 & 0.095 & 1.168 & 0.243 & \\
Strategic IS $\times$ SIZE $\rightarrow$ FP & -0.060 & 0.064 & 0.933 & 0.351 & \\
\hline
\end{tabular}

Table VII. Interaction effects of heterogeneity and control variables on the relationship between strategic IS and FP 


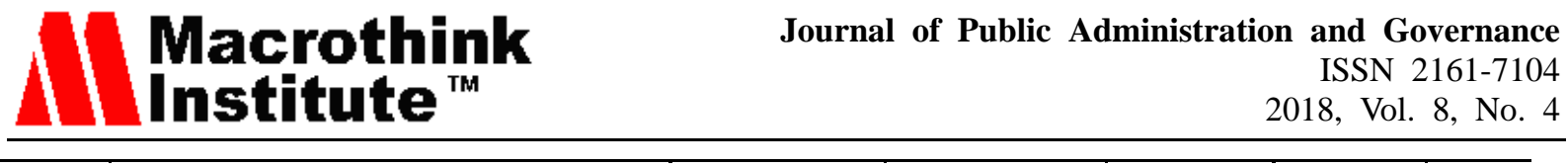

\begin{tabular}{clcccccc} 
Case & \multicolumn{1}{c}{ Relationship } & $\beta$ & S.E. & & p-value & $\mathrm{R}^{2}$ \\
\hline \multirow{4}{*}{1} & HE $\rightarrow$ FP & -0.013 & 0.057 & & 0.231 & 0.817 & \\
& HE $\times$ GDPS $\rightarrow$ FP & -0.056 & 0.057 & 0.982 & 0.326 & \\
& GDPS $\rightarrow$ FP & -0.021 & 0.065 & 0.326 & 0.745 & \\
& Strategic IS $\rightarrow$ FP & 0.577 & 0.057 & 10.099 & 0.000 & $\mathbf{4 2 . 9 9 \%}$ \\
& Strategic IS $\times$ HE $\rightarrow$ FP & -0.150 & 0.219 & 0.687 & 0.492 & \\
& Strategic IS $\times$ HE $\times$ GDPS $\rightarrow$ FP & 0.091 & 0.121 & 0.747 & 0.455 & \\
& Strategic IS $\times$ GDPS $\rightarrow$ FP & 0.062 & 0.109 & 0.573 & 0.566 & \\
\hline & SIZE $\rightarrow$ FP & 0.138 & 0.059 & 2.321 & 0.020 & \\
& HE $\rightarrow$ FP & -0.051 & 0.064 & 0.798 & 0.425 & \\
& HE $\times$ SIZE $\rightarrow$ FP & 0.051 & 0.071 & 0.716 & 0.474 & \\
Strategic IS $\rightarrow$ FP & 0.566 & 0.068 & 8.332 & 0.000 & $\mathbf{4 1 . 6 2 \%}$ \\
& Strategic IS $\times$ SIZE $\rightarrow$ FP & 0.004 & 0.070 & 0.061 & 0.951 & \\
& Strategic IS $\times$ HE $\rightarrow$ FP & -0.176 & 0.209 & 0.842 & 0.400 & \\
& Strategic IS $\times$ HE $\times$ SIZE $\rightarrow$ FP & 0.074 & 0.096 & 0.771 & 0.441 & \\
\hline
\end{tabular}

In Cases 1 and 2, it was identified that size influences FP, and none of the two- and three-way interaction effects significantly moderated the key relation (strategic IS $\rightarrow$ FP; $p>0.05$ ) with dynamism, heterogeneity, and control variables (see Table VI and VII).

Table VIII. Interaction effects of hostility and control variables on the relationship between strategic IS and FP

\begin{tabular}{|c|c|c|c|c|c|c|}
\hline Case & Relationship & $\beta$ & S.E. & $\mathrm{t}$ & p-value & $\mathrm{R}^{2}$ \\
\hline \multirow{7}{*}{1} & $\mathrm{HO}->\mathrm{FP}$ & -0.117 & 0.071 & 1.656 & 0.098 & \multirow{7}{*}{$44.95 \%$} \\
\hline & $\mathrm{HO} \times \mathrm{GDPS}->\mathrm{FP}$ & -0.154 & 0.053 & 2.902 & 0.004 & \\
\hline & GDPS -> FP & 0.009 & 0.063 & 0.142 & 0.887 & \\
\hline & Strategic IS -> FP & 0.561 & 0.052 & 10.723 & 0.000 & \\
\hline & Strategic IS $\times$ HO $->$ FP & -0.119 & 0.146 & 0.815 & 0.415 & \\
\hline & Strategic IS $\times$ HO $\times$ GDPS $->$ FP & 0.142 & 0.054 & 2.641 & 0.008 & \\
\hline & Strategic IS $\times$ GDPS $->$ FP & 0.088 & 0.118 & 0.740 & 0.459 & \\
\hline \multirow{7}{*}{2} & SIZE $->$ FP & 0.132 & 0.056 & 2.378 & 0.017 & \multirow{7}{*}{$45.09 \%$} \\
\hline & $\mathrm{HO}->\mathrm{FP}$ & -0.080 & 0.061 & 1.310 & 0.190 & \\
\hline & $\mathrm{HO} \times \mathrm{SIZE}->\mathrm{FP}$ & -0.027 & 0.049 & 0.555 & 0.579 & \\
\hline & Strategic IS -> FP & 0.534 & 0.057 & 9.429 & 0.000 & \\
\hline & Strategic IS $\times$ SIZE $->$ FP & -0.064 & 0.055 & 1.152 & 0.249 & \\
\hline & Strategic IS $\times$ HO $->$ FP & -0.137 & 0.150 & 0.913 & 0.361 & \\
\hline & Strategic IS $\times \mathrm{HO} \times$ SIZE $->$ FP & -0.138 & 0.135 & 1.022 & 0.307 & \\
\hline
\end{tabular}

Organizational size influences FP ( $\mathrm{p}$ value < 0.05), see Table VI, VII, and VII. However, none of the moderation effects (two- and three-way interaction) of hostility, heterogeneity and control variables showed statistical significance $(\mathrm{p}>0.05)$. On the other hand, Case 1 (Table VIII) showed that negative GDP per sector influences the relationship between hostility and FP. The three-way interaction between strategic IS, hostility, and GDPS interestingly exerted a positive moderating effect on the relationship between strategic IS and FP, increasing the 
path coefficient to 0.703 ( $p<0.05$, see Table VIII). Finally, in Case 2 (Table VIII), none of the moderating effects of the interactions were statistically significant $(p>0.05)$.

The coefficient of determination $\left(\mathrm{R}^{2}\right)$ measures the variance of the strategic IS variable and provides a measure of the structural model's quality. Cohen (1988) suggests that in the social and behavioral sciences, $\mathrm{R}^{2}$ values of two per cent, 13 per cent, and 26 per cent represent small, medium, and large effects, respectively. As evidenced by the $\mathrm{R}^{2}$ values in Tables $\mathrm{V}$ to VIII, the coefficients of determination indicate that the relationship between strategic IS and FP is characterized by a large effect.

\section{Discussion and Conclusions}

This study empirically examines how strategic information systems influence firm performance. Specifically, the study investigates the moderating effect of two- and three-way interactions involving environmental uncertainty, organizational size, and GDP per sector on the fundamental relationship between strategic information systems and firm performance. The proposed strategic IS models all had high explanatory power in terms of $\mathrm{R}^{2}$ (ranging from 39.5 per cent to 45.09 per cent). Given these findings, this study offers several contributions to improve both theory building and practice related to strategic IS of firm operations in turbulent environments.

Statistical tests of H1 (i.e., strategic IS $\rightarrow$ FP) showed strong, significant path coefficients indicating that effective use of IS enables strategic planning capabilities to positively influence firm performance. This is true of all phases of SP including the communication of strategic objectives, the scanning of the external environment, improving internal competence, the formulation and implementation of organizational plans and action strategies, and the implementation of overall organizational strategy. This study finds that strategic IS creates IS/IT business value for the strategic planning process independent of the macro condition economy in a developing country and an uncertain environment.

Tests of Hypothesis 4 (strategic IS $\times \mathrm{HO} \times$ GDPS $\rightarrow \mathrm{FP}$ ) provide support for a three-way interaction effect between strategic IS, environmental hostility, and sector GDP on firm performance. One major finding produced by the analyses was that strategic IS had a more substantial influence on firm performance under hostile environmental conditions and during periods of economic crisis or contraction. To illustrate, greater economic crisis (as measured by negative GDP per sector) and environmental hostility yielded a 20 per cent increase in the strength of the positive relationship between strategic IS and firm performance. Service and manufacturing sectors tend to have greater IS embedded in their strategic planning processes. As a result, this study demonstrates that effective use of IS enables business strategy capabilities to understand the environment - external and internal - to formulate, implement, and control strategies to survive an economic crisis with intense hostility caused by price wars and competition.

This study did not explore the direct effect of organizational size, GDP per sector, or environmental uncertainty on firm performance. However, the tests of interaction effects suggest a statistically significant and positive relationship between organization size and firm 
performance $(\mathrm{p}<0.05)$. This is consistent with past work by an IT research center at the Getulio Vargas Foundation (Meirelles, 2016), which found that large companies in the service industry spent 10.8 per cent of revenues on IT/IS in Brazil in 2015. Large firms in the Brazilian manufacturing sector spent a large portion (4.6 per cent) of revenues on IT also. The analyses of interaction effects also reveal how environmental uncertainty can affect firm performance. More specifically, one of the control variables (i.e., GDP per sector) had a strong, positive moderating effect on the relationship between environmental hostility and firm performance. This is directly applicable to the turbulent Brazilian economic environment in which firms engage in price competition and seek to diversify their products in terms of quality. This moderating effect can have negative implications for some firms; 580,000 companies ceased activities in 2015 (IBGE, 2016).

The analyses showed that when the economic environment is more turbulent (i.e., GDP -3.8 per cent), the moderation of dynamism and heterogeneity does not have a significant effect on the relationship between strategic IS and firm performance (Hypothesis 2 was not supported). This result differed from the results of studies on stable economies (Chanchun et al., 2006; Newkirk \& Lederer, 2006; Pavlou \& El Sawy, 2010), and this could be expected because during a long period of economic crisis (2015 and 2016), companies plan and execute productivity-directed actions for the short term (efficiency and effectiveness of resources use). The consequences of a lack of alignment between IT/IS and business become less significant to innovators and create considerable diversity in customers, product lines, and competitors. In these conditions, companies in a turbulent environment identify more threats than opportunities, and firm strategic orientations focus on protecting market share in mature industries or markets primarily through improving operational efficiency (Miller \& Friesen, 1983; Yayla \& Hu, 2012).

The study similarly analyzes the moderating effects of GDP per sector and organization size in the relationship between strategic IS and FP, which also showed no statistical significance (Hypothesis 3 was not supported). The study demonstrates that in economic turbulence, there is no significant difference in the ways that companies anticipate and accurately plan for the future scenario. The study finds that a turbulent scenario did not create a significant difference between companies according to size or sector. However, the study shows that large organizations show greater potential for IT expenditure (Meirelles, 2016) to influence firm performance.

Taken together, the results of this study show that effective use of strategic information systems enables capabilities and several benefits to influence firm performance. Further, IT/IS can contribute to the creation of business value to support business strategy. As such, the results indicate that the adoption of strategy IS solutions in an uncertain environment (or during times of economic crisis) can help firms to perform well despite the volatility of the operating environment around them.

\subsection{Implications for Practice}

First, previous strategic studies have confirmed that strategic planning contributes to improved firm performance. Strategic planning can help companies understand the greater 
benefits of implementing strategic planning practices.

Second, effective use of strategic IS can help raise the awareness among businesses as to how IS enables strategic planning capabilities that support their efforts towards achieving objectives and realize greater value from the planning process.

Third, manager must be more conscientious when attempting to understand the uncertainty environment - hostility, dynamism, and heterogeneity - within the context of a crisis economy and when addressing organizational challenges.

Fourth, to understand the role of the uncertainty of hostility in the context of an economic crisis, administrators should carefully consider their efforts in each phase of the strategic IS and become more flexible to vary their decisions in strategic planning.

This study found that managers must focus on the uncertainty of hostility in an economic crisis. Strategic IS's value creation should provide information for decision making to develop strategies that compete for company survival whether through resource efficiencies, product quality differentiation, or customer relationships. Strategic IS should help managers to analyze the external environment producing greater knowledge of competitors, resources, customers, and regulators to improve firm performance. However, managers must balance efforts in planning strategies for future scenarios by anticipating different environment uncertainties.

The study showed that managers cannot disregard the degree of hostility and environmental uncertainty in the economic crisis context and should not underestimate their actions to achieve short- and medium-term survival strategic objectives. It is evident that several factors influence the survival of companies in strong hostility and economic crisis environments; however, managers' planning may be inefficient and ineffective. Managers should pause and reconsider what they need to emphasize in their efforts and recognize that effective use of strategic IS enables the strategic planning process and creates many benefits to help organizations in uncertain environments and economic turbulence.

\subsection{Future Research and Study Limitations}

Whereas this study focuses on strategic IS as an antecedent to firm performance, future research could verify the effects of strategic IS on improvisational and dynamic capabilities and develop commensurate scales to measure the effects. Some studies demonstrate that strategic planning routines are extremely rigid and do not enable capabilities to create innovation (Song, Zhao, Arend, \& Im, 2015). Future research can identify how strategic IS impacts innovation strategies.

Although the study provides significant insight into how strategic IS can contribute in times of environmental uncertainty and economic crisis, it is important to acknowledge its limitations. First, the sample from which data were collected was not selected entirely at random. However, the use of non-random samples is not uncommon (Ray et al., 2009; Yayla $\& \mathrm{Hu}, 2012$ ). In addition, given the desire to evaluate the Brazilian economy, selecting a sample that effectively represents that economy was important. Therefore, the sample was 
similarly proportioned to the Brazilian economy in terms of GDP per sector (using data from IBGE [2016]).

Another potential weakness of this study is the decision to use latent variables (which require some assumptions related to their measurement). Latent variables may not perfectly reflect the realities of executive perceptions of strategic IS, firm performance, or environmental uncertainty.

\section{References}

Arvidsson, V., Holmström, J., \& Lyytinen, K. (2014). Information systems use as strategy practice: A multi-dimensional view of strategic information system implementation and use. Journal of Strategic Information Systems, 23(1), 45-61. https://doi.org/10.1016/j.jsis.2014.01.004

Atkinson, A. A., Kaplan, R. S., Matsumura, E. M., \& Young, S. M. (2011). Management Accounting: Information for Decision-making and Strategy Execution (6th ed.). Upper Saddle River: Prentice Hall.

Carlson, K. D., \& Wu, J. (2012). The illusion of statistical control: control variable practice in management research. Organizational Research Methods, 15(3), 413-435. https://doi.org/10.1177/1094428111428817

Chan, Y. E., \& Huff, S. L. (1992). Strategy: an information systems research perspective. The Journal of Strategic Information Systems, 1(4), 191-204. https://doi.org/10.1016/0963-8687(92)90035-U

Chan, Y. E., Sabherwal, R., \& Thatcher, J. B. (2006). Antecedents and outcomes of strategic IS alignment: an empirical investigation. IEEE Transactions on Engineering Management, 53(1), 27-47. https://doi.org/10.1109/TEM.2005.861804

Chanchun, Y. E., Sabherwal, R., \& Thatcher, J. B. (2006). Antecedents and outcomes of strategic IS alignment: An empirical investigation. IEEE Transactions on Engineering Management. https://doi.org/10.1109/TEM.2005.861804

Chen, D. Q., Mocker, M., Preston, D. S., \& Teubner, A. (2010). Information Systems Strategy: Reconceptualization, Measurement, and Implications. MIS Quarterly, 34(2), 233-259. https://doi.org/10.2307/20721426

Dameron, S., Lê, J. K., \& Lebaron, C. (2015). Materializing Strategy and Strategizing Materials: Why Matter Matters. British Journal of Management, 26(S1), S1-S12. https://doi.org/10.1111/1467-8551.12084

Davenport, T. H., Harris, J. G., \& Morison, R. (2010). Analytics at Work: Smarter Decisions, Better Results. Harvard Business School Press Books. Retrieved from http://www.amazon.com/dp/1422177696\%5Cnhttp://books.google.com/books?id=2otJuvfvfl gC\&pgis $=1$

Faul, F., Erdfelder, E., Lang, A. G., \& Buchner, A. (2007). G*Power 3: A flexible statistical power analysis program for the social, behavioral, and biomedical sciences. Behavior Research Methods, 39(2), 175-191. https://doi.org/10.3758/BF03193146

Grant, R. M. (2003). Strategic planning in a turbulent environment: Evidence from the oil majors. Strategic Management Journal, 24(6), 491-517. https://doi.org/10.1002/smj.314 
Hair, J. F., Hult, G., Ringle, C., \& Sarstedt, M. (2013). A Primer on Partial Least Squares Structural Equation Modeling (PLS-SEM). Thousand Oaks: Sage.

Henseler, J., \& Fassott, G. (2010). Testing moderating effects in PLS path models: an illustration of available procedures. In V. Esposito Vinzi, W. W. Chin, J. Henseler, \& H. Wang (Eds.), Handbook of Partial Least Squares: Concepts, Methods and Applications (pp. 713-735). Berlin: Springer. https://doi.org/10.1007/978-3-540-32827-8_31

Henseler, J., Ringle, C. M., \& Sinkovics, R. R. (2009). The use of partial least squares path modeling in international marketing. Advances in International Marketing, 20, 277-319. https://doi.org/10.1108/S1474-7979(2009)0000020014

Hill, C., Jones, G., \& Schilling, M. (2014). Strategic Management: Theory: An Integrated Approach. Cengage Learning.

Hitt, M. A., Keats, B. W., \& DeMarie, S. M. (1998). Navigating in the new competitive landscape: Building strategic flexibility and competitive advantage in the 21 st century. Academy of Management Perspectives, 22-42. https://doi.org/10.5465/AME.1998.1333922

I.M.F. (2016). International Monetary and Financial Committee, Thirty-third Meeting. $\begin{array}{llll}\text { Retrieved } \quad \text { February 23, from } & \text { 2017, }\end{array}$ http://www.imf.org/External/spring/2016/imfc/statement/eng/bra.pdf

I.M.F. (2017). 2017 Article IV Consultation-Press Release; Staff Report; and Statement by the Executive Director for Germany; IMF Country Report No. 17/192; June 13, 2017, (17). https://doi.org/1AGOEA2015002

IBGE. (2016). Contas Nacionais Trimestrais. Retrieved February 23, 2017, from ftp://ftp.ibge.gov.br/Contas_Nacionais/Contas_Nacionais_Trimestrais/Comentarios

Johnson, A. M., \& Lederer, A. L. (2013). IS Strategy and IS Contribution: CEO and CIO Perspectives. Information Systems Management, 30(4), 306-318. https://doi.org/10.1080/10580530.2013.832962

Kaplan, R. S., \& Norton, D. P. (2008). The Execution Premium: Linking Strategy to Operations for Competitive Advantage. Boston: Harvard Business School Press.

Kearns, G. S., \& Sabherwal, R. (2006). Strategic Alignment Between Business and Information Technology: A Knowledge-Based View of Behaviors, Outcome, and Consequences. Journal of Management Information Systems, 23(3), 129-162. https://doi.org/10.2753/MIS0742-1222230306

Kenworthy, T. P., \& Verbeke, A. (2015). The future of strategic management research: Assessing the quality of theory borrowing. European Management Journal, 33(3), 179-190. https://doi.org/10.1016/j.emj.2015.03.007

Kim, G., Shin, B., Kim, K. K., \& Lee, H. G. (2011). IT Capabilities, Process-Oriented Dynamic Capabilities, and Firm Financial Performance. Journal of Association for Information Systems, 12(7), 487-517. https://doi.org/10.17705/1jais.00270

Lederer, A. L., \& Mendelow, A. L. (1986). Issues in information systems planning. Information \& Management. https://doi.org/10.1016/0378-7206(86)90027-3

Leidner, D. E., Lo, J., \& Preston, D. S. (2011). An empirical investigation of the relationship 
of IS strategy with firm performance. Journal of Strategic Information Systems, 20(4), 419-437. https://doi.org/10.1016/j.jsis.2011.09.001

Lumpkin, G. T., \& Dess, G. G. (2001). Linking two dimensions of entrepreneurial orientation to firm performance: The moderating role of environment and industry life cycle. Journal of Business Venturing, 16(5), 429-451. https://doi.org/10.1016/S0883-9026(00)00048-3

Maharaj, S., \& Brown, I. (2015). The impact of shared domain knowledge on strategic information systems planning and alignment. South African Journal of Information Management, 17(1), 1-12. https://doi.org/10.4102/sajim.v17i1.608

Mao, H., Liu, S., \& Zhang, J. (2014). How the effects of IT and knowledge capability on organizational agility are contingent on environmental uncertainty and information intensity. Information Development, 31(4), 1-25. https://doi.org/10.1177/0266666913518059

Marabelli, M., \& Galliers, R. D. (2017). A reflection on information systems strategizing: the role of power and everyday practices. Information Systems Journal, 27(3), 347-366. https://doi.org/10.1111/isj.12110

Marôco, J. (2010). Análise de Equações Estruturais: Fundamentos Teóricos, Software e Aplicações. Portugal: Pêro Pinheiro.

Meirelles, F. S. (2016). Pesquisa Anual do Uso de TI nas empresas. São Paulo: Fundação Getulio Vargas, Escola de Administração de Empresas de São Paulo, Centro de Tecnologia de Informação Aplicada. FGV-EAESP-CIA.

Melville, N., Kraemer, K., \& Gurbaxani, V. (2004). Review: Information Technology and Organizational Performance: An Integrative Model of IT Business Value. MIS Quarterly, 28(2), 283-322. https://doi.org/10.2307/25148636

Merali, Y., Papadopoulos, T., \& Nadkarni, T. (2012). Systems Information systems strategy : Past, present, future? Journal of Strategic Information Systems, 21(2), 125-153. https://doi.org/10.1016/j.jsis.2012.04.002

Mikalef, P., \& Pateli, A. (2017). Information technology-enabled dynamic capabilities and their indirect effect on competitive performance: Findings from PLS-SEM and fsQCA. Journal of Business Research, 70, 1-16. https://doi.org/10.1016/j.jbusres.2016.09.004

Mikalefdletear, P., \& Pateli, A. (2017). Information technology-enabled dynamic capabilities and their indirect effect on competitive performance: Findings from PLS-SEM and fsQCA. Journal of Business Research, 70, 1-16. https://doi.org/10.1016/j.jbusres.2016.09.004

Miller, D., \& Friesen, P. H. (1983). Strategy-making and enviroment: the third link. Strategic Management Journal, 4, 221-235. https://doi.org/10.1002/smj.4250040304

Mintzberg, H., Ahlstrand, B. W., \& Lampel, J. (2009). Strategy safari: The complete guide through the wilds of strategic management (2nd ed.). Harlow:UK: Financial Times Prentice Hall.

Mithas, S., Ramasubbu, N., \& Sambamurthy, V. (2011). How Information Management Capability Influences Firm Performance. MIS Quarterly, 35(1), 237-256. https://doi.org/10.2307/23043496

Mithas, S., Tafti, A., \& Mitchell, W. (2013). How a Firm's Competitive Environment and Digital Strategy Posture Influence Digital Business Strategy. MIS Quarterly, 37(2), 511-536. 
https://doi.org/10.1257/jel.50.4.1051

Mostaghel, R., Oghazi, P., Beheshi, H. ., \& Hultman, M. (2015). Strategic use of enterprise systems among service firms: Antecedents and consequences. Journal of Business Research, 1544-1549. https://doi.org/10.1016/j.jbusres.2015.01.049

Newkirk, H. E., \& Lederer, A. L. (2006). The effectiveness of strategic information systems planning under environmental uncertainty. Information \& Management, 43(4), 481-501. https://doi.org/10.1016/j.im.2005.12.001

Ong, T. S., \& Teh, B. H. (2009). The use of financial and non-financial performance measures in the Malaysian manufacturing companies. The IUP Journal of Accounting Research and Audit Practices, 8(1), 23-30.

Ouakouak, M. L., \& Ouedraogo, N. (2013). The mediating role of employee strategic alignment in the relationship between rational strategic planning and firm performance: A European study. Canadian Journal of Administrative Sciences, 30(3), 143-158. https://doi.org/10.1002/cjas.1259

Papke-Shields, K. E., Malhotra, M. K., \& Grover, V. (2006). Evolution in the strategic manufacturing planning process of organizations. Journal of Operations Management, 24(5), 421-439. https://doi.org/10.1016/j.jom.2005.11.012

Park, S., Lee, H., \& Chae, S. W. (2017a). Rethinking balanced scorecard ( BSC ) measures : formative versus reflective measurement models. https://doi.org/10.1108/IJPPM-08-2015-0109

Park, S., Lee, H., \& Chae, S. W. (2017b). Rethinking balanced scorecard (BSC) measures: formative versus reflective measurement models. International Journal of Productivity and Performance Management, 66(1), 92-110. https://doi.org/10.1108/IJPPM-08-2015-0109

Pavlou, P. A., \& El Sawy, O. A. (2006). From IT Leveraging Competence to Competitive Advantage in Turbulent Environments: The Case of New Product Development. Information Systems Research, 17(3), 198-227. https://doi.org/10.1287/isre.1060.0094

Pavlou, P. A., \& El Sawy, O. A. (2010). The "third hand": IT-enabled competitive advantage in turbulence through improvisational capabilities. Information Systems Research, 21(3), 443-471. https://doi.org/10.1287/isre.1100.0280

Philip, G. (2007). IS Strategic Planning for Operational Efficiency. Information Systems Management, 24(3), 247-264. https://doi.org/10.1080/10580530701404504

Ray, G., Wu, D., \& Konana, P. (2009). Competitive environment and the relationship between IT and vertical integration. Information Systems Research, 20(4), 585-603. https://doi.org/10.1287/isre.1080.0202

Ringle, C. M., Bido, D. S., \& Da Silva, D. (2014). Structural equation modeling with the SmartPLS. Brazilian Journal of Marketing, 13(2), 53-76. https://doi.org/10.5585/remark.v13i2.2717

Ringle, C. M., Sarstedt, M., \& Straub, D. W. (2012). Editor's Comments: A Critical Look at the Use of PLS-SEM. MIS Quarterly, 36(1), iii-xiv.

Ringle, C. M., Wende, S., \& Will, A. (2005). SmartPLS 2.0.M3. Hamburg: SmartPLS. Retrieved from http://www.smartpls.de 
Rouhani, S., Ashrafi, A., Ravasan, A. Z., \& Afshari, S. (2016). The impact model of business intelligence on decision support and organizational benefits. Journal of Enterprise Information Management, 29(1), 19-50. https://doi.org/10.1108/JEIM-12-2014-0126

Sabherwal, R., \& Chan, Y. E. (2001). Alignment Between Business and IS Strategies: A Study of Prospectors. Information Systems Research, 12(1), 11-33. https://doi.org/10.1287/isre.12.1.11.9714

Sabherwal, R., \& King, W. R. (1995). An Empirical Taxonomy of the Decision-Making Processes Concerning Strategic Applications of Information Systems. Journal of Management Information Systems. https://doi.org/10.1080/07421222.1995.11518064

Schilke, O. (2014). On the Contingent Value of Dynamic Capabilities for Competitive Advantage: the Nonlinear Moderating Effect of Environmental Dynamism. Academy of Management Journal, 51(2), 179-203. https://doi.org/10.1002/smj.02099

Segars, A. H., \& Grover, V. (1998). Strategic Information Systems Planning Success: An Investigation of the Construct and Its Measurement. MIS Quarterly, 22(2), 139-163. https://doi.org/10.2307/249393

Segars, A. H., Grover, V., \& Teng, J. T. C. (1998). Strategic information systems planning: Planning system dimensons, internal coalignment, and implications for planning $\begin{array}{llll}\text { effectiveness. } & \text { Decision } & \text { Sciences, } & 29(2),\end{array}$ https://doi.org/10.1111/j.1540-5915.1998.tb01579.x

Shollo, A., \& Galliers, R. D. (2016). Towards an understanding of the role of business intelligence systems in organisational knowing. Information Systems Journal, 26(4), 339-367. https://doi.org/10.1111/isj.12071

Singh, S. K., Watson, H. J., \& Watson, R. T. (2002). EIS support for the strategic management process. Decision Support Systems, 33(1), 71-85. https://doi.org/10.1016/S0167-9236(01)00129-4

Song, M., Zhao, Y., Arend, R. J., \& Im, S. (2015). Strategic planning as a complex and enabling managerial tool. Strategic Management Journal.

Sosik, J. J., Kahai, S. S., \& Piovoso, M. J. (2009). Silver Bullet or Voodoo Statistics?: A Primer for Using the Partial Least Squares Data Analytic Technique in Group and Organization Research. Group \& Organization Management, 34(1), 5-36. https://doi.org/10.1177/1059601108329198

Tallon, P. P., Kraemer, K. L., \& Gurbaxani, V. (2000). Executives' Perceptions of the Business Value of Information Technology: A Process-Oriented Approach. Journal of Management Information Systems, $16(4), \quad 145-173$. https://doi.org/10.1080/07421222.2000.11518269

Teubner, R. A. (2013). Theory, Practice, and Challenges for Future Research. Business \& Information Systems Engineerin, 5(4), 243-257. https://doi.org/10.1007/s12599-013-0279-z

Urbach, N., \& Ahlemann, F. (2010). Structural equation modeling in Information Systems research using partial least squares. Journal of Information Technology Theory and Application, 11(2), 5-40. https://doi.org/10.1037/0021-9010.90.4.710

Vijayasarathy, L., \& Sabherwal, R. (1994). An empirical investigation of the antecedents of telecommunication-based interorganizational systems. European Journal of Information 
Systems.

Wade, M., \& Hulland, J. (2004). the Resource-Based View and Information Systems Research: Review, Extension, and Suggestions for Future Research. MIS Quarterly, 28(1), 107-142. https://doi.org/10.2307/25148626

Ward, J. M. (2012). Journal of Strategic Information Systems Information systems strategy: Quo vadis? Journal of Strategic Information Systems, 21(2), 165-171. https://doi.org/10.1016/j.jsis.2012.05.002

Whittington, R. (2014). Journal of Strategic Information Systems Information Systems Strategy and Strategy-as-Practice : A joint agenda q. Journal of Strategic Information Systems, 23(1), 87-91. https://doi.org/10.1016/j.jsis.2014.01.003

Wilden, R., \& Gudergan, S. P. (2015). The impact of dynamic capabilities on operational marketing and technological capabilities: investigating the role of environmental turbulence. Journal of the Academy of Marketing Science, 43(2), 181-199. https://doi.org/10.1007/s11747-014-0380-y

Wolf, C., \& Floyd, S. W. (2017). Strategic Planning Research: Toward a Theory-Driven Agenda. Journal of Management, 43(6), 1754-1788. Retrieved from http://journals.sagepub.com/doi/10.1177/0149206313478185

Yayla, A. A., \& Hu, Q. (2012). The impact of IT-business strategic alignment on firm performance in a developing country setting: exploring moderating roles of environmental uncertainty and strategic orientation. European Journal of Information Systems, 21(4), 373-387. https://doi.org/10.1057/ejis.2011.52

Yoshikuni, A. C., \& Albertin, A. L. (2014). Model Analysis of the Relationship Between Strategic Organization Knowledge and the Use of Information Systems in Firm Performance in Brazil. Chinese Business Review, 13(5), 301-319.

Yoshikuni, A. C., \& Albertin, L. A. (2017). IT-Enabled Dynamic Capability on Performance : an Empirical Study of. RAE, 57(maio-jun), 215-231. https://doi.org/10.1590

Yoshikuni, A. C., Favaretto, J. E. R., Albertin, A. L., \& Meirelles, F. S. (2018). The Influences of Strategic Information Systems on the Relationship between Innovation and Organizational. Brailian Business Review. https://doi.org/dx.doi.org/10.15728/bbr.2018.15.5.3

Yoshikuni, A. C., Machado-da-silva, F. N., Albertin, A. L., \& Meirelles, F. S. (2014). Strategy as a mediator of the relationship between use of is and business performance. REBRAE-Revista Brasileira de Estratégia, 7(maio/ago), 223-241. https://doi.org/10.7213/rebrae.07.002.AO07

Appendix A: Abbreviated Questionnaire

All items were presented in the form of a seven-point Likert-type scale ranging from 1 (strongly agree) to 7 (strongly disagree).

The use of strategic IS enables support to disseminate the strategic objectives ...

- $\quad\left(\mathrm{SO}_{-}\right.$) to teams understanding the goals/objectives of the organization.

- (SO_2) communicating targets/objectives are being met.

- (SO_3) monitoring targets/objectives are being met. 
The use of strategic IS supports environmental analysis ...

- (EA_1) to scan external factors that affect the organization.

- (EA_2) to identify the existence of positive and negative conditions (e.g., trends, market, competitors, and customers).

- (EA_3) to find reliable internal resources to formulate strategies.

The use of strategic IS enables firms to develop strategy formulation ...

- $\quad\left(\mathrm{SF}_{-} 1\right)$ to develop initiatives and action plans to achieve goals/objectives.

- $\left(\mathrm{SF} \_2\right)$ to collect and select rational actions to achieve goals/targets.

- (SF_3) with information to develop alternatives strategies.

The use of strategic IS enables firms to implement strategy ...

- (SI_1) to execute action plans to achieve long-term goals.

- (SI_2) to translate strategy into operations.

- (SI_3) to coordinate working activities to achieve goals.

The use of strategic IS support to control strategy ...

- $\quad\left(\mathrm{SC}_{-} 1\right)$ to monitor the implementation and outcome of strategy.

- $\quad\left(\mathrm{SC} \_2\right)$ to analyze and monitor the efficient and effective use of resources to achieve goals.

- (SC_3) to compare actual performance against budgets, goals, standards, and benchmarks.

Environmental uncertainty

Dynamism

- (DI_1) Products/services in our industry become obsolete quickly.

- (DI_2) The product/service technologies in our industry change quickly.

- (DI_3) The rate of innovation (geared towards gaining competitive advantages and achieving business goals) is high in our industry.

With respect to heterogeneity, in our industry, there is considerable diversity in:

- (HE_1) customer buying habits.

- (HE_2) the nature of competition.

- (HE_3) product lines.

- (HE_4) channels of distribution.

- (HE_5) geographic concentration of firms.

With respect to hostility, the survival of this organization is currently threatened by:

- (HO_1) tough price competition.

- (HO_2) tough competition in product/service quality.

- (HO_3) tough competition in product/service differentiation.

Firm Performance:

-(FP_1) The company reaches its goals for profitability to satisfy shareholders.

-(FP_2) The business is efficient in terms of spending (i.e., cost management, expenses, and investments) to meet productivity goals.

-(FP_3) The company reaches its goals with respect to revenues.

-(FP_4) Customers remain loyal to the company. 
-(FP_5) The market associates the company's image (brand) with the quality of the services and/or products it represents.

Appendix B: Cross-loadings to determine discriminant validity of the first model

\begin{tabular}{|c|c|c|c|c|c|c|c|c|c|c|}
\hline $\begin{array}{l}\text { First-order } \\
\text { variables }\end{array}$ & Items & 1 & 2 & 3 & 4 & 5 & 6 & 7 & 8 & 9 \\
\hline 1 - Strategic & SO_1 & 0.771 & 0.541 & 0.498 & 0.542 & 0.448 & 0.442 & 0.181 & 0.267 & -0.013 \\
\hline \multirow[t]{2}{*}{ objectives } & SO_2 & 0.836 & 0.464 & 0.520 & 0.581 & 0.521 & 0.430 & 0.115 & 0.284 & -0.145 \\
\hline & SO_3 & 0.863 & 0.514 & 0.525 & 0.581 & 0.468 & 0.434 & 0.109 & 0.246 & -0.062 \\
\hline \multirow{3}{*}{$\begin{array}{l}2 \text { - Environmental } \\
\text { analysis }\end{array}$} & EA_1 & 0.504 & 0.839 & 0.526 & 0.409 & 0.492 & 0.483 & 0.121 & 0.329 & -0.071 \\
\hline & EA_2 & 0.491 & 0.795 & 0.650 & 0.494 & 0.518 & 0.445 & 0.154 & 0.239 & -0.008 \\
\hline & EA_3 & 0.507 & 0.813 & 0.555 & 0.459 & 0.463 & 0.372 & 0.167 & 0.332 & -0.008 \\
\hline 3 - Strategy & SF_1 & 0.497 & 0.601 & 0.781 & 0.469 & 0.482 & 0.405 & 0.153 & 0.199 & -0.081 \\
\hline \multirow[t]{2}{*}{ formulation } & SF_2 & 0.543 & 0.585 & 0.865 & 0.531 & 0.494 & 0.442 & 0.245 & 0.278 & -0.034 \\
\hline & SF_3 & 0.537 & 0.607 & 0.877 & 0.511 & 0.501 & 0.457 & 0.057 & 0.265 & -0.073 \\
\hline 4 - Strategy & SI_1 & 0.550 & 0.356 & 0.440 & 0.806 & 0.381 & 0.433 & 0.161 & 0.145 & -0.022 \\
\hline \multirow[t]{2}{*}{ implementation } & SI_2 & 0.577 & 0.550 & 0.515 & 0.819 & 0.511 & 0.457 & 0.225 & 0.334 & -0.055 \\
\hline & SI_3 & 0.548 & 0.434 & 0.494 & 0.804 & 0.457 & 0.359 & 0.164 & 0.262 & -0.023 \\
\hline \multirow[t]{3}{*}{5 - Strategy control } & SC_1 & 0.392 & 0.377 & 0.403 & 0.295 & 0.681 & 0.375 & 0.093 & 0.231 & -0.113 \\
\hline & SC_2 & 0.467 & 0.501 & 0.419 & 0.432 & 0.759 & 0.329 & 0.126 & 0.247 & -0.137 \\
\hline & SC_3 & 0.471 & 0.493 & 0.512 & 0.530 & 0.842 & 0.322 & 0.174 & 0.254 & -0.102 \\
\hline \multirow{5}{*}{$\begin{array}{l}6 \text { - Firm } \\
\text { performance }\end{array}$} & FP_1 & 0.406 & 0.418 & 0.366 & 0.423 & 0.356 & 0.860 & 0.181 & 0.184 & -0.177 \\
\hline & FP_2 & 0.411 & 0.415 & 0.416 & 0.402 & 0.326 & 0.857 & 0.165 & 0.205 & -0.106 \\
\hline & FP_3 & 0.404 & 0.431 & 0.434 & 0.416 & 0.326 & 0.841 & 0.165 & 0.196 & -0.201 \\
\hline & FP_4 & 0.302 & 0.270 & 0.305 & 0.344 & 0.145 & 0.616 & 0.114 & 0.049 & -0.022 \\
\hline & FP_5 & 0.492 & 0.481 & 0.457 & 0.404 & 0.485 & 0.686 & 0.109 & 0.365 & -0.125 \\
\hline \multirow[t]{3}{*}{7 - Dynamism } & DI_1 & 0.111 & 0.109 & 0.102 & 0.190 & 0.133 & 0.135 & 0.727 & 0.132 & 0.148 \\
\hline & DI_2 & 0.125 & 0.164 & 0.182 & 0.149 & 0.099 & 0.167 & 0.835 & 0.212 & 0.211 \\
\hline & DI_3 & 0.142 & 0.140 & 0.123 & 0.198 & 0.184 & 0.133 & 0.743 & 0.356 & 0.157 \\
\hline \multirow[t]{5}{*}{8 - Heterogeneity } & HE_1 & -0.069 & 0.028 & 0.047 & 0.026 & 0.105 & -0.024 & 0.386 & 0.184 & 0.176 \\
\hline & HE_2 & -0.035 & -0.041 & 0.051 & 0.024 & -0.053 & -0.107 & 0.211 & -0.140 & 0.270 \\
\hline & HE_3 & 0.179 & 0.259 & 0.158 & 0.157 & 0.223 & 0.150 & 0.218 & 0.645 & 0.005 \\
\hline & HE_4 & 0.230 & 0.301 & 0.270 & 0.315 & 0.222 & 0.196 & 0.393 & 0.778 & 0.161 \\
\hline & HE_5 & 0.267 & 0.231 & 0.249 & 0.220 & 0.246 & 0.191 & 0.216 & 0.724 & 0.039 \\
\hline \multirow[t]{3}{*}{9 - Hostility } & HO_1 & -0.074 & -0.028 & -0.023 & -0.046 & -0.130 & -0.179 & 0.164 & -0.044 & $\mathbf{0 . 8 7 3}$ \\
\hline & HO_2 & -0.063 & -0.029 & -0.098 & -0.029 & -0.144 & -0.051 & 0.147 & 0.035 & 0.620 \\
\hline & HO_3 & -0.063 & -0.026 & -0.105 & -0.004 & -0.074 & -0.081 & 0.215 & 0.122 & 0.642 \\
\hline
\end{tabular}

Note: The values of the correlations between LV and square roots of the AVE values are in the main diagonal (in bold)

\section{Copyright Disclaimer}

Copyright for this article is retained by the author(s), with first publication rights granted to the journal.

This is an open-access article distributed under the terms and conditions of the Creative Commons Attribution license (http://creativecommons.org/licenses/by/4.0/). 